\title{
Karsten Reise
}

\section{Metapopulation structure in the lagoon cockle Cerastoderma lamarcki in the northern Wadden Sea}

Received: 18 March 2002 / Revised: 11 July 2002 / Accepted: 12 July 2002 / Published online: 27 November 2002

(C) Springer-Verlag and AWI 2002

\begin{abstract}
Benthic invertebrates in discontinuous inshore habitats and with short or no pelagic larval dispersal are likely to exhibit regional metapopulation dynamics with partially isolated local populations. Near the island of Sylt, the bivalve Cerastoderma (Cardium) lamarcki (Reeve, 1844, syn. in part with C. glaucum Bruguiére, 1789) was widespread in intertidal seagrass beds, coexisting with the sibling species $C$. edule (Linné, 1758). However, the last $C$. lamarcki in this habitat was found in 1980. At present the lagoon cockle is restricted to disjunct ditches, creeks and ponds within island salt marshes. There it differs in year-class structure between localities. Successful recruitment events did not coincide. At one locality, a period with regular recruitment was followed by 5 years of recruitment failure, resulting in an overaged population probably at the rim of extinction. In a nearby brackish pond, extinction was followed by recolonization 3 years later. Other lagoonal habitats which seem to be suitable are without cockles. It is speculated that small and isolated habitats occasionally receive colonizers by eggs and juveniles adhering to avian vectors.
\end{abstract}

Keywords Cockles · Population dynamics . Metapopulation $\cdot$ Dispersal $\cdot$ Wadden Sea

\section{Introduction}

The metapopulation concept was proposed in order to study population dynamics in a binary landscape of suitable and unsuitable habitat patches (Hanski and Gilpin 1991; Hanski 1999). Attention was focused on the degree of isolation between patches of individuals which may

Communicated by W. Armonies, M. Strasser and K. Reise

K. Reise $(\bullet)$

Alfred-Wegener-Institut, Wattenmeerstation Sylt, 25992 List, Germany

e-mail: kreise@awi-bremerhaven.de

Tel.: +49-4651-956110, Fax: +49-4651-956200 become extinct or newly founded. These patches of individuals are regarded as local populations if they sustain themselves over several generations and exhibit dynamics partially independent from other such populations within a region. Local extinction events and limited dispersal may cause a fraction of suitable habitat to remain empty. A regional metapopulation may rather abruptly drop to extinction when habitat loss and fragmentation disconnects small local populations completely.

This approach to spatial population ecology may be fruitful in the case of coastal, marine benthic invertebrates, (1) where these are restricted to discontinuous habitats such as estuaries, lagoons, sedimentary bays, rocky headlands or islands, and (2) when dispersal between these disjunct habitats is limited either by offshore currents and eddies or by a low mobility of the organisms. The latter may be the case in taxa where development is holobenthic (i.e. all meiofauna, peracarid crustaceans, oligochaetes) or where the pelagic larval phase is short. Thus, metapopulation dynamics may be characteristic for many coastal invertebrates.

In the Wadden Sea, brackish reed marshes, salt marshes and upper mud flats have been embanked and converted to land for several centuries (Wolff 1992; Reise 1996). These inshore habitats partly emerged anew in front of the sea-dykes but the areal extension gradually diminished and habitats became fragmented. Species restricted to inshore habitats may face extinction once the distance between remaining habitat patches becomes wider than their dispersal range, and habitat patches become so small that chance events bring about local extinctions. In the northern Wadden Sea, the lagoon cockle Cerastoderma (Cardium) lamarcki (Reeve, 1844) is today restricted to small waterbodies within disjunct salt marshes. The hypothesis is that this species forms a regional metapopulation.

The common cockle $C$. edule (Linné, 1758) is distributed along the coasts from the Barents Sea to West Africa (Hayward and Ryland 1995). From this species, two sibling species have been separated, the southern $C$. glaucum (Bruguiére, 1789) and the northern C. lamarcki. This 
Table 1 Ecological niches in the sibling cockle species Cerastoderma edule and C. lamarcki / C. glaucum according to Armonies (1992), Brock (1979, 1980a, 1980b), Koulman and Wolff (1977) Lauckner (1972), Russell and Petersen (1973), Rygg (1970)

\begin{tabular}{lll}
\hline Attributes & C. edule & C. lamarcki / C. glaucum \\
\hline Habitat type & Open coast and estuaries & Estuaries and Lagoons \\
Burying ability & High & Low \\
Adapted to air exposure & Yes & No \\
Temperature range $\left({ }^{\circ} \mathrm{C}\right)$ & $3-25$ & $0-32$ \\
Optimum $\left({ }^{\circ} \mathrm{C}\right)$ & 10 & 20 \\
Salinity tolerated $(\mathrm{psu})$ & $10-35$ & $4-60$ \\
Eggs & Small - many, pelagic & Large - few, benthic \\
Larval longevity and dispersal & Long & Short \\
Juvenile mobility & Tidal drift, crawling & Byssal attachment, climbing \\
\hline
\end{tabular}

had been disputed but was finally accepted (Mars 1951; Boyden 1971; Kingston 1974a; Brock 1978; Hummel et al. 1994). However, the northern $C$. lamarcki was often lumped with C. glaucum (Rygg 1970; Brock 1979; Hummel et al. 1994). More recent genetic studies suggest a separate status for $C$. lamarcki, although there may be a genetic cline along the Atlantic coast towards the Mediterranean Sea (Brock and Christiansen 1989; Brock and Wolowicz 1994).

Both lagoon cockles overlap with $C$. edule but generally live further inshore (Petersen 1958; Rasmussen 1973; van Urk 1973), have a lower metabolic rate and a higher thermal tolerance (Ansell et al. 1981; Boyden 1972a). An ecological comparison (Table 1) suggests the existence of large, coherent populations in C. edule, while C. lamarcki and C. glaucum may be structured into metapopulations distributed over insular habitats not regularly connected by dispersal. The egg and larval attributes found near Sylt (Lauckner 1972) may be a regional adaptation, and have not been confirmed by other studies (André et al. 1999; Kingston 1974a, 1974b).

\section{Methods}

Study area

The northern Wadden Sea is a coastal stretch in the eastern North Sea (Fig. 1), about $150 \mathrm{~km}$ long and $20 \mathrm{~km}$ wide, with more than 20 dune and marshy islands and high sands scattered over tidal flats drained by deep channels and small creeks (Bartholdy and Pejrup 1994; De Jong et al. 1999; Gätje and Reise 1998; Kohlus and Küpper 1998). Seagrass beds in the upper intertidal cover some $40 \mathrm{~km}^{2}$, mostly at the leeside of the islands (Reise 2001). Cerastoderma lamarcki was found there until 1980. Sites surveyed in this study for $C$. lamarcki are creeks, ponds and ditches in salt marshes of the islands. Three sites received particular attention (see Fig. 1).

- Hallig Langeness (HL): marshy island with pastures flooded 10 to 30 times annually. Ditches and creeks are partly vegetated with Zostera marina, Ruppia maritima and filamentous green algae. The bottom is muddy, and sites with $C$. lamarcki are permanently filled with water. The web of drainage ditches is connected with ambient tidal waters and salinity was 32-35 psu (July 2001). The ditches surveyed were within $5 \mathrm{~km}$ and connected with each other.

- Ellenbogen salt marsh on the island of Sylt, $40 \mathrm{~km}$ from HL: Isolated brackish pond (PS) varying in size between 54 and $90 \mathrm{~m}^{2}$. The ambient salt marsh is irregularly flooded, in some years not at all and in others up to eight times (e.g. winter 2001/2002). Salinity in summer varies between 6 and 18 psu but adopts intermittently marine conditions when reached by

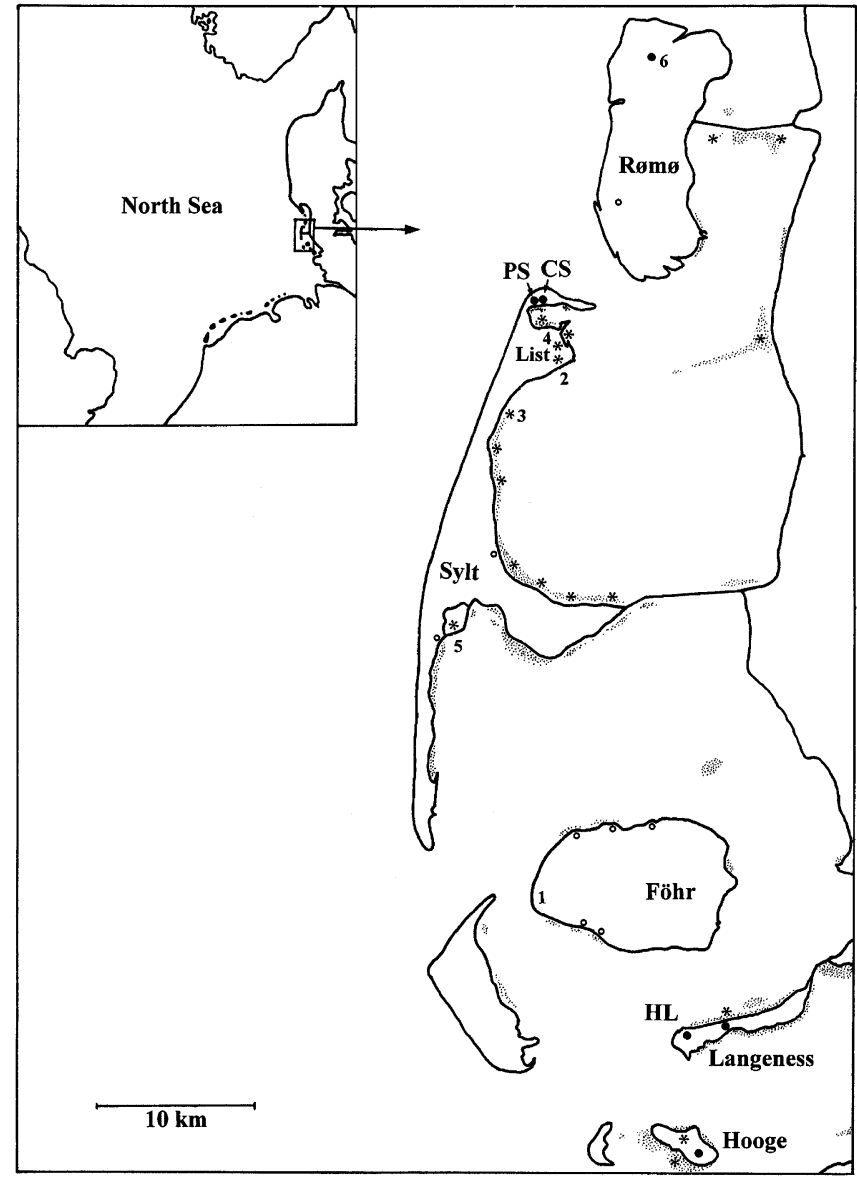

Fig. 1 Central part of the northern Wadden Sea surveyed for Cerastoderma lamarcki since the 1970s. Filled circles live records in salt marshes (Hooge 1987, 1994; Langeness 1990, 2001; Sylt 1992-2001; Rømø 2001), open circles potentially suitable but empty salt-marsh habitat (1993-2001), asterisks only empty shells since 1980. Intertidal seagrass beds are stippled. HL Hallig Langeness, PS Ellenbogen salt-marsh pond, Sylt, CS Ellenbogen salt-marsh creek, Sylt. Sites 1 Gross Dunsum, Föhr, 2 List, Sylt, 3 Vogelkoje Kampen, Sylt, 4 Lister Koog, Sylt, 5 Rantum Becken, Sylt, 6 Juvre, northern Røm $\varnothing$

storm tides in winter. Depth in summer is up to $0.5 \mathrm{~m}$. The bottom is mostly sandy with some scattered growth of $R$. maritima. In addition to $C$. lamarcki, the benthic macrofauna comprised Arenicola marina, Polydora cornuta, Pygospio elegans, Nereis diversicolor, Mya arenaria and in the water Crangon crangon, Pomatoschistus microps and Gasterosteus aculeatus (1995 to 2001). 
- Salt-marsh creek on the island of Sylt (CS), about $400 \mathrm{~m}$ distance from PS: Creek about $500 \mathrm{~m}$ long and up to $20 \mathrm{~m}$ wide meandering through a salt marsh. At the mouth, this creek is partly barred by a sandy spit but is regularly reached by tidal waters during spring high tides. In the deepest part near the mouth, the creek is up to $1.5 \mathrm{~m}$ deep but elsewhere average depth was $0.5 \mathrm{~m}$. The submerged area varied between 3,100 and $5,700 \mathrm{~m}^{2}$. The edges of the creek are bounded by cliffs. The bottom is mostly sandy, with a few silty depressions. This is where most $C$. lamarcki were found. Zostera marina and filamentous green algae occurred in a few patches. The benthic macrofauna is similar to that of adjacent tidal flats and comprised some 34 species, plus five species of fish. Salinity ranged between 30 and 36 psu. During exceptional storm tides $\mathrm{CS}$ and PS are connected.

\section{Surveys}

Many lagoonal sites on the islands in the northern Wadden Sea were surveyed once or several times since 1990 (Fig. 1). Regular and quantitative sampling concentrated on PS and CS from 1993 to 2001. Cockles $>10 \mathrm{~mm}$ were collected by hand raking within squares of $0.04 \mathrm{~m}^{2}$. At PS between 20 and 95 such samples were taken at intervals and at CS up to 820 were taken. In addition, samples of $10 \mathrm{~cm}^{2}$ were sieved through $0.25 \mathrm{~mm}$ meshes to check for the presence of spat. Intertidal seagrass beds of the region have been visited at irregular intervals since the 1970s.

\section{Results}

From a large and continuous population to small and isolated populations

Among the mollusc shells of a kitchen midden excavated near Gross Dunsum, Island of Föhr (Fig. 1 site 1; Friesenmuseum Wyk/Föhr), dated to 1000 AD, I spotted one Cerastoderma lamarcki. At an excavation in the village of List (Island of Sylt; Fig. 1 site 2), I found several shells of $C$. lamarcki at a site where, according to Newig (1980), a tidal creek became filled with sand in the 18th century. These cockles have lived in the area at least 200 years ago.

Early surveys of the regional fauna did not separate C. lamarcki from C. edule. However, in the late 1960s, C. lamarcki was commonly found within seagrass beds in the upper tidal zone around Sylt together with C. edule, usually aggregated in puddles filled with residual water during low tide (Lauckner 1972, 1974, personal communication). This pattern persisted until 1980 when I recorded the last intertidal patch of $C$. lamarcki among seagrasses near Vogelkoje Kampen, island of Sylt (Fig. 1 site 3). Abundant shells at several seagrass beds bear witness of a former, wide distribution in the upper intertidal zone in the region of the northern Wadden Sea (Fig. 1). However, no living specimens have been found anywhere in the tidal zone of the entire region since 1980.

Apparently, no attention had been given to C. lamarcki in creeks, ponds and ditches within the salt marshes of the region prior to the 1980s. I recorded this species in ditches on Hallig Hooge in 1987 (and again in 1994), on Hallig Langeness in 1990 (and again in 2001), and since 1992 on Sylt (Fig. 1: PS, CS). Empty shells at two

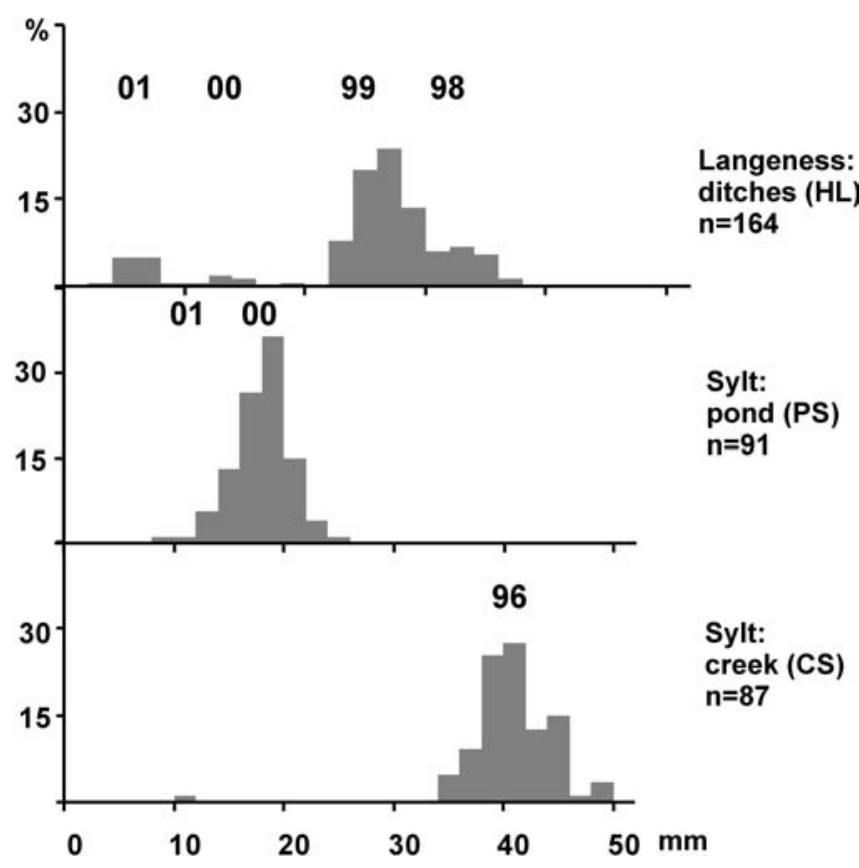

Fig. 2 Shell length frequency distributions obtained for Cerastoderma lamarcki at three sites in July 2001. Years of age classes according to annual growth rings are indicated above peaks in the size spectrum. The numbers of individuals measured are given below sites

other salt-marsh sites on Sylt (Lister Koog and Rantum Becken; see Fig. 1 sites 4 and 5)suggest earlier but now extinct occurrences in this kind of habitat. On the islands of Föhr, Sylt and Røm $\varnothing$, nine salt-marsh creeks which are very similar to CS were surveyed, and in only one of these was $C$. lamarcki encountered (Juvre on northern Rømø, October 2001; Fig. 1 site 6). C. edule was generally absent from these salt-marsh habitats. Only at $\mathrm{CS}$ were a few $C$. edule encountered within patches of C. lamarcki.

\section{Differential age structures of local populations}

Two sites on Sylt (PS and CS: $400 \mathrm{~m}$ apart) and one on Langeness (HL: $40 \mathrm{~km}$ away) showed diverging size frequency distributions of $C$. lamarcki in July 2001 (Fig. 2). At least four year-classes were present on Langeness, with a cohort from 1999 dominating. In the salt-marsh pond on Sylt (PS), a cohort from 2000 prevailed and in a nearby creek (CS), a cohort from 1996. Years with recruitment success did not coincide, suggesting that age structures are the outcome of local conditions.

\section{Population development in a creek}

In a salt-marsh creek (CS) on Sylt, size frequency distributions indicate regular recruitment and the presence of several year-classes for the early 1990s (Fig. 3). Strong cohorts originated from 1992 and 1995. In the last 


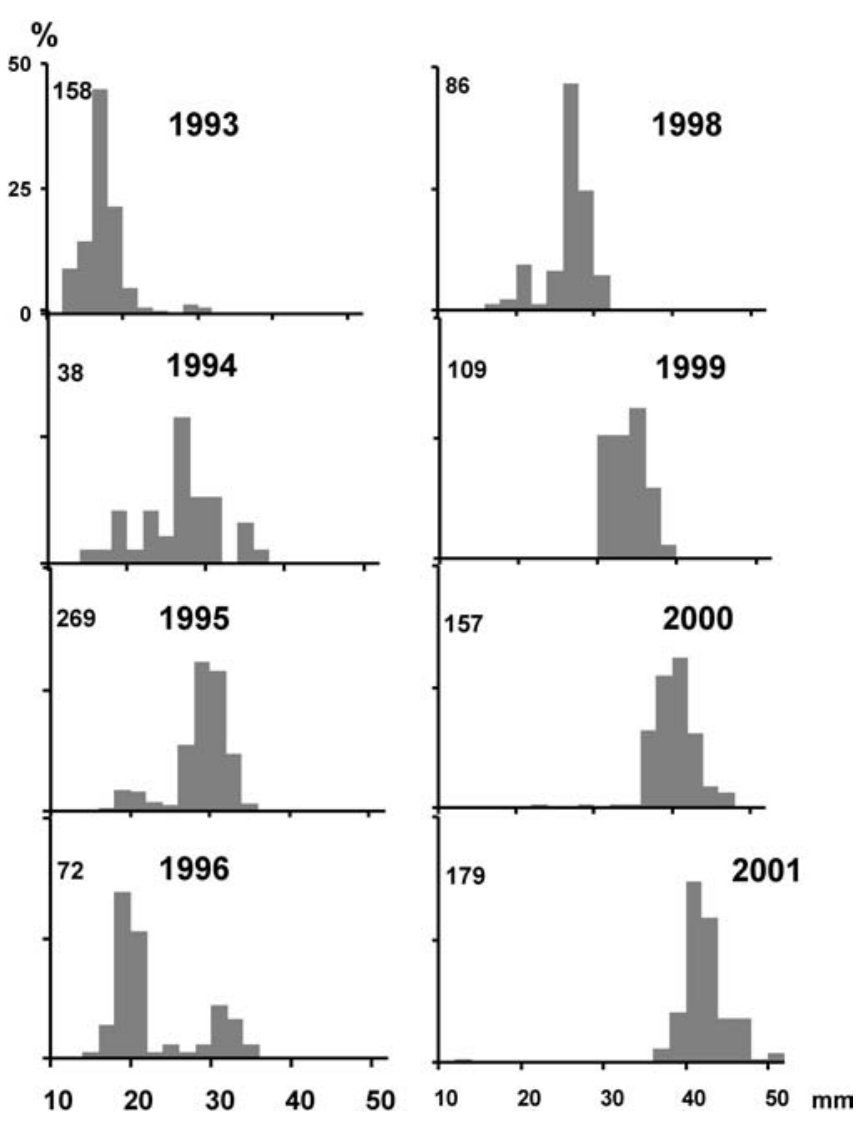

Fig. 3 Shell length frequency distributions obtained for Cerastoderma lamarcki $>10 \mathrm{~mm}$ from a salt-marsh creek $(C S)$ on Sylt between 1993 and 2001. To the left, numbers of individuals measured are given, and to the right the year of investigation. Dates of sampling: 27 June 1993, 16 July 1994, 30 June 1995, 2 September 1996, 17 May 1998, 13 June 1999, 15 May 2000, 24 September 2000, 23 May 2001, 28 July 2001

4 years, however, almost all cockles belonged to a cohort from 1996. There was no recent significant recruitment resulting in an overaged population in 2001.

The population size is difficult to estimate because of conspicuous aggregations of adult $C$. lamarcki at a few silty depressions in the otherwise sandy bed of the creek. Spat $(<5 \mathrm{~mm}$ shell length) was more evenly distributed but also tended to aggregate at silty patches. In July 1995 , spat density was $12.4 \pm 14.2$ on $10 \mathrm{~cm}^{2}(n=30)$. In the entire creek there may have been in the order of $40 \times 10^{6}$ juveniles in the submerged area of the creek $\left(3,130 \mathrm{~m}^{2}\right.$ at that time). Cockles $>10 \mathrm{~mm}$ were counted by hand raking 77 random squares of $400 \mathrm{~cm}^{2}$. Density was 1.0 2.7 . Of these 77 cockles sampled, 62 belong to a cohort from 1992 and 15 from 1994, according to annual growth rings and shell length. Thus, in addition to the spat, roughly $10^{5}$ adult cockles lived in the entire creek in summer 1995.

The subsequent winter was unusually severe and most of the C. edule died on the adjacent tidal flats (Strasser et al. 2001a). The creek was covered by ice for about 2 months, and many of the older $C$. lamarcki died subsequently. In 150 random samples of $400 \mathrm{~cm}^{2}, 156$ adult

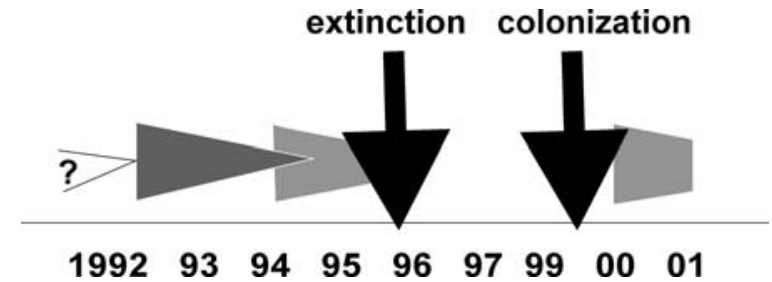

Fig. 4 Scheme of Cerastoderma lamarcki year-classes present in a brackish salt-marsh pond (PS) on Sylt from 1992 to 2001

cockles were counted (August 1996) of which 145 belonged to the cohort from the previous year. Thus, the total number of adult cockles was roughly in the same order of magnitude as in the year before. There was a good spatfall that summer, and in September mean density was still $1.7 \pm 0.9$ on $10 \mathrm{~cm}^{2}(n=10)$ and thus in the order of $10^{6}$ in the entire creek.

In subsequent years no more spat were encountered but the cohort from 1996 persisted. In June 1999 their total number was estimated to be about $10^{5}$ (58 cockles in 40 random samples of $400 \mathrm{~cm}^{2}$ ), while in July 2001 the estimate was only 18,000 (102 cockles in 820 random samples of $400 \mathrm{~cm}^{2}$ and a submerged area of $5,700 \mathrm{~m}^{2}$ ).

Two patches with high densities in previous years now had dead cockles only. Green algal masses from adjacent tidal flats had been washed into the creek by a storm tide earlier in July and had decayed. The algae became covered with sulphur bacteria and the water underneath turned black and smelled intensely of hydrogen sulphide. This disturbance of the creek environment presumably killed all cockles in the anterior half of the creek. The posterior (inner) part received no algal masses and remained unaffected.

\section{Population extinction and recolonization in a pond}

Similar to the creek, a nearby brackish pond (PS) connected to the creek only during exceptionally high storm tides, was populated by a strong cohort of $C$. lamarcki from 1992 (Fig. 4). This was superseded by a cohort from 1994 which died subsequent to the severe winter of $1995 / 1996$. In spite of intensive surveying of the entire pond (about $75 \mathrm{~m}^{2}$ ) no cockles were found from 1996 to 1999 . However, in summer 2000 spat was encountered. In September, 103 cockles (mean shell length $11.9 \pm 2.5 \mathrm{~mm}$, range $4-18 \mathrm{~mm}$ ) were found by hand raking 20 random samples of $400 \mathrm{~cm}^{2}$. The estimate for the entire pond was about $10^{4}$ cockles. Next year in July, about 1,400 were still alive (59 cockles in 95 random samples of $400 \mathrm{~cm}^{2}$; submerged area $90 \mathrm{~m}^{2}$ ), and no spat were encountered that summer.

Of the 103 cockles sampled in 2000, seven had a conspicuous shell anomaly not observed before. In the anterior half of the shell, rips were fused pairwise and the posterior half was almost smooth with scant ribs. Of 101 cockles sampled in 2001, the shells of four were anomalous. 


\section{Discussion}

This ongoing study on the fate of Cerastoderma lamarcki in the northern Wadden Sea is used here to discuss the suitability and implications of the metapopulation concept in the marine coastal environment. Prior to 1980 , the population was probably more or less coherent by its occurrence in upper intertidal seagrass beds which may have connected scattered occurrences in salt-marsh ditches, creeks and ponds on the islands. However, during the last 20 years the intertidal zone remained without C. lamarcki. This presumably resulted in widely spaced remnant populations in lagoonal salt-marsh habitats without regular exchange of propagules. The data suggest that local population dynamics are at least partially independent of each other because age structures are different and successful recruitment events do not coincide. While there was no recruitment in a salt-marsh creek in 2000 , a nearby pond about $400 \mathrm{~m}$ away received plenty of spat which survived. In this pond, a former population went extinct and a new one appeared 3 years later. There are similar habitats in the region which are empty, and two of these were once occupied. This pattern is in line with metapopulation dynamics as described by Hanski (1999). However, several questions remain open.

Why did C. lamarcki vanish from the tidal zone?

The lagoon cockle generally occurred in the tidal zone of the northern Wadden Sea at several sites in the 1960s and 1970s (Brock 1979, 1980a; Lauckner 1972; own observations) but declined and were gone by 1980. Shells of this species are still abundant at these sites. Often the two valves are still hinged together in clay sediment. However, it should be noted that shell material resembling $C$. lamarcki has been collected throughout the Wadden Sea. This may be in part of young Pleistocene or early Holocene origin, and thus does not necessarily relate to some recent occurrence (see de Boer and de Bruyne 1991; Schreitling 1963; personal observations).

Intertidal cockles are well known to be susceptible to harsh winter conditions often followed by strong recruitment (Strasser et al. 2001a, 2001b). Boyden (1972b) recorded that $C$. edule and $C$. glaucum were similarly affected by a cold winter in the Crouch estuary, England. The winter 1978/1979 was particularly severe and killed almost all intertidal C. edule near Sylt (Reise 1985). However, C. lamarcki survived until 1980, partly with a cohort from 1977 (own observation). Similarly, it survived the severe winter of 1995/1996 in a salt-marsh creek (this study), while $C$. edule in the intertidal died (Strasser et al. 2001a). Thus, a severe winter cannot be held responsible for wiping out the intertidal population of $C$. lamarcki. In contrast with the southern Wadden Sea, the seagrass beds as the main habitat of $C$. lamarcki did not decline in the northern Wadden Sea (Reise 2001). According to Lauckner (1974) trematode infections were higher in $C$. edule than in $C$. lamarcki in the tidal zone near Sylt. Thus it is unlikely that parasites eliminated the intertidal population. Differential predation by crabs and birds on the two cockles seems to be rather unlikely given their close similarity in shell size and shape.

Koulman and Wolff (1977) and Brock (1979) showed that $C$. edule reburied significantly faster than $C$. lamarcki, which may explain the absence of the latter from wave-exposed sites. Following this argument, it may be speculated that more frequent storm surges since the 1970s, as measured by the duration of water levels $>1.5 \mathrm{~m}$ above mean high water near Sylt (Hofstede 1999), might have affected $C$. lamarcki in the tidal zone while inside the shelter of salt marshes they were not affected and could persist. If this is true, salt-marsh habitats may serve as a refuge during decadal phases of increased storminess. In the Dutch Wadden Sea, C. lamarcki is only found on the islands of Texel and Schiermonnikoog in salt-marsh habitats (Kuijper 2000).

\section{Extinction, dispersal and colonization}

For bivalve population sizes in enclosed water bodies only rough estimates are possible. In a salt-marsh creek on Sylt (CS), numbers of adult cockles were in the order of $10^{5}$, and decreased to $10^{4}$ in 2001 after a disturbance event. In the nearby pond (PS), numbers decreased from $10^{4}$ to $10^{3}$. When spatfall occurred, numbers intermittently increased by one or two orders of magnitude. It is apparent from these numbers that in natural habitats it is almost impossible to distinguish a local extinction with a new colonization after some years from an intermittent bottleneck situation with very few individuals. This is particularly a problem in organisms such as cockles with a longevity of 5 years or more.

In the small pond (PS) I assume that I have not overlooked any survivors after the severe winter 1995/1996 but cannot exclude the possibility that a few cockles escaped my attention. If there were no survivors, how did the spatfall in 2000 come about? A massive immigration of larvae from the nearby creek population in the course of an inundation of the entire salt marsh during a storm tide can be excluded. Such inundations which connect pond and creek only occurred in the winter season, while propagules are released in summer (Boyden 1971; Beushausen 1994; Kingston 1974a, 1974b).

An alternative could be accidental introduction of some eggs or juveniles by birds in 1999. These immigrants may have given birth to the observed spat in the following year. Lauckner (1972) reports that eggs of C. lamarcki adhere to the walls of Petri dishes. Juveniles climb on submerged plants and attach to substrates with their byssal gland (Muus 1967; Petersen and Russell 1971). I observed oystercatchers (Haematopus ostralegus) feeding on adult cockles in the creek. This could be an opportunity for propagules to attach to an avian vector and become transported to disjunct water bodies such as a pond in a salt marsh. 
The observed shell anomalies in the pond population could be an inbreeding defect, pointing to a very small group of survivors or initial colonizers. Similar anomalies in C. glaucum have been observed in Britain (Petersen and Russell 1971).

What are the prospects of regional survival?

The small size of the habitats as well as of the isolated populations in the island salt marshes constitute a threat to these $C$. lamarcki populations. Local extinction is a likely event in spite of the potential longevity of cockles. This is shown by the pond population as well as by the superannuated population in the creek with repeated recruitment failure and the extra mortality caused by decaying algal masses in 2001. If these two small populations at the northern end of Sylt become extinct, the nearest recolonization sources are $20-40 \mathrm{~km}$ away on other islands. Dispersal of the lecitotrophic larvae with their short swimming period (Lauckner 1972) from these distant sources to Sylt by the coastal currents seems almost impossible. For Swedish waters, planktotrophic larvae lasting 2-3 weeks have been reported (André et al. 1999; Lindegarth et al. 1995). Still, it does not seem likely that they will disperse over wide distances from one salt-marsh creek to colonize another. Either avian vectors help in dispersal or the time has come when the intertidal seagrass beds become colonized again from remnant salt-marsh populations, reconnecting the now widely spaced populations.

If not, the regional metapopulation is prone to extinction. Presumably it would be rather easy to rescue this lagoonal cockle population by transplanting mature individuals. With transplants it could also be tested whether the presently unoccupied creeks and seagrass beds constitute suitable habitats. This would answer the question of whether there are plenty of suitable but empty habitats because extinction events are frequent while dispersal is rather limited. Also the question could be answered whether the intertidal habitats are still suitable or whether the frequency of storm tides or other factors preclude the occurrence of the slow-burying $C$. lamarcki. The ethical question arises of whether the present state of the regional metapopulation warrants such an interference.

\section{Conclusions}

Knowledge on the dynamics of the population of local populations of $C$. lamarcki in the northern Wadden Sea is rather fragmentary. It may be concluded, however, that the metapopulation concept is applicable because local populations show independent dynamics, are unstable, and there may be one case of a successful recolonization where a previous population became extinct. Unfortunately, nothing is known about dispersal between local populations. The crucial question of whether there is a regional balance between local extinctions and recoloni- zations cannot be answered. It may very well be that C. lamarcki is in a long-term decline. It first went extinct from intertidal seagrass beds and is now losing one local salt-marsh population after the other because of insufficient means of dispersal. Thus, the most pressing task is to test for avian transport of propagules.

There are several other inshore invertebrate species with no or rather limited means of larval dispersal, i.e. all meiofauna, the cnidarian Protohydra leuckarti, the turbellarian Procerodes littoralis, the nemertine Lineus viridis, polychaetes such as Fabricia sabella and Manayunkia aestuarina, and tubificid oligochaetes, gastropods such as Phytia myosotis, Alderia modesta, Hydrobia ventrosa, Littorina saxatilis, the bivalve Abra tenuis, talitrid amphipods, isopods such as Cyathura carinata and Sphaeroma hookeri, all of which occur at inshore lagoons and salt marshes (see Barnes 1994). In view of their fragmentary habitat along modern coasts in northwestern Europe, the spatial aspects of these populations need to be investigated with a focus on dispersal. The metapopulation concept may guide such studies (Hanski 2001).

Acknowledgements I thank Heike Beushausen and Markus Quack who diligently sampled a salt-marsh creek on Sylt for Cerastoderma lamarcki in 1993 and 1996, respectively. Elisabeth Herre helped in preparing the figures. Inken Kruse, Herman Hummel and Karel Essink helped with interesting references, and the latter is thanked in particular for improving the manuscript.

\section{References}

André C, Lindegarth M, Jonsson PR, Sundberg P (1999) Species identification of bivalve larvae using random amplified polymorphic DNA (RAPD): differentiation between Cerastoderma edule and C. lamarcki. J Mar Biol Assoc UK 79:563-565

Ansell AD, Barnett PRO, Bodoy A, Massé H (1981) Upper temperature tolerances of some European molluscs. III. Cardium glausum, C. tuberculatum and C. edule. Mar Biol 65:177-183

Armonies W (1992) Migratory rhythms of drifting juvenile molluscs in tidal waters of the Wadden Sea. Mar Ecol Prog Ser 83:197-206

Barnes RSK (1994) The brackish-water fauna of northwestern Europe. Cambridge University Press, Cambridge

Bartholdy J, Pejrup M (1994) Holocene evolution of the Danish Wadden Sea. Senckenbergiana Maritima 24:187-209

Beushausen H (1994) Die Makrofauna eines Salzwiesenpriels: Eine spezifische Fauna oder lediglich eine verarmte Wattfauna? Master's thesis, University of Göttingen

Boer TW de, Bruyne RH de (1991) Schelpen van de Friese Waddeneilanden. Overzicht van alle mariene autochtone weekdieren (Mollusca) en aangespoelde schelpen. Fryske Akademy, Leeuwert. W Backhuys, Oegstgeest, The Netherlands

Boyden CR (1971) A comparative study of the reproductive cycles of the cockles Cerastoderma edule and C. glaucum. J Mar Biol Assoc UK 51:605-622

Boyden CR (1972a) The behaviour, survival and respiration in air of the cockles Cerastoderma edule and C. glaucum. J Mar Biol Assoc UK 52:661-680

Boyden CR (1972b) Relationship of size to age in the cockles Cerastoderma edule and $C$. glaucum from the River Crouch estuary, Essex. J Conchol 27:475-489

Brock V (1978) Morphological and biochemical criteria for the separation of Cardium glaucum (Bruguière) from Cardium edule (L.). Ophelia 17:207-214 
Brock V (1979) Habitat selection of two congeneric bivalves, Cardium edule and $C$. glaucum in sympatric and allopatric populations. Mar Biol 54:149-156

Brock V (1980a) The geographical distribution of Cerastoderma (Cardium) edule (L.) and C. lamarcki (Reeve) in the Baltic and adjacent seas related to salinity and salinity fluctuations. Ophelia 19:207-214

Brock V (1980b) Evidence for niche differences in sympatric populations of Cerastoderma edule and C. lamarcki. Mar Ecol Prog Ser 2:75-80

Brock V, Christiansen G (1989) Evolution of Cardium (Cerastoderma) edule, C. lamarcki and C. glaucum: studies of DNAvariation. Mar Biol 102:505-511

Brock V, Wolowicz M (1994) Comparisons on European populations of the Cerastoderma glaucum/C. lamarcki complex based on reproductive physiology and biochemistry. Oceanol Acta 17:97-103

De Jong F, Bakker JF, Berkel CJM van, Dankers NMJA, Dahl K, Gätje C, Marencic H, Potel P (1999) Wadden Sea quality status report. Wadden Sea Ecosystem No. 9. Common Wadden Sea Secretariat, Wilhelmshaven, Germany

Gätje C, Reise K (1998) Ökosystem Wattenmeer. Austausch-, Transport- und Stoffumwandlungsprozesse. Springer, Berlin Heidelberg New York

Hanski I (1999) Metapopulation ecology. Oxford University Press, Oxford

Hanski I (2001) Population dynamic consequences of dispersal in local populations and in metapopulations. In: Clobert $\mathbf{J}$, Danchin E, Dhondt AA, Nichols JD (eds) Dispersal. Oxford University Press, Oxford

Hanski I, Gilpin M (1991) Metapopulation dynamics: brief history and conceptual domain. Biol J Linn Soc 42:3-16

Hayward PJ, Ryland JS (1995) Handbook of the marine fauna of north-west Europe. Oxford University Press, Oxford

Hofstede J (1999) Process-response analysis for Hörnum tidal inlet in the German sector of the Wadden Sea. Quat Int 60:107-117

Hummel H, Wolowicz M, Bogaards RH (1994) Genetic variability and relationships for populations of Cerastoderma edule and of the C. glaucum complex. Neth J Sea Res 33:81-89

Kingston PF (1974a) Studies on the reproductive cycles of Cardium edule and C. glaucum. Mar Biol 28:317-323

Kingston PF (1974b) Some observations on the effects of temperature and salinity upon the growth of Cardium edule and C. glaucum larvae in the laboratory. J Mar Biol Assoc UK 54:309-317

Kohlus J, Küpper H (1998) Umweltatlas Wattenmeer. Vol 1. Nordfriesisches und Dithmarscher Wattenmeer. Ulmer, Stuttgart, Germany

Koulman JG, Wolff WJ (1977) The Mollusca of the estuarine region of the rivers Rhine, Meuse, and Scheldt in relation to the hydrography of the area. V. The Cardiidae. Basteria 41:21-32

Kuijper W (2000) De weekdieren van de Nederlands Brakwatergebieden (Mollusca). Ned Faun Meded 12:41-120
Lauckner G (1972) Zur Taxonomie, Ökologie und Physiologie von Cardium edule L. und Cardium lamarcki Reeve. Thesis, Kiel University

Lauckner G (1974) Zur Trematodenfauna der Herzmuscheln Cardium edule und Cardium lamarcki. Helgol Wiss Meeresunters 22:377-400

Lindegarth M, André C, Jonsson PR (1995) Analysis of the spatial variability in abundance and age structure of two infaunal bivalves, Cerastoderma edule and $C$. lamarcki, using hierarchical sampling programs. Mar Ecol Prog Ser 116:85-97

Mars P (1951) Essai d'interprétation des formes généralement groupées sous le nom de Cardium edule Linné. Bull Mus Hist Nat Marseille 11:1-31

Muus BJ (1967) The fauna of Danish estuaries and lagoons. Medd Danm Fisk Havunders 5:1-316

Newig J (1980) Zur Entwicklung des Listlandes auf Sylt in den letzten drei Jahrhunderten: ein historisch-kartographischer Vergleich. Nordfriesisches Jahrb Neue Folge 16:69-74

Petersen GH (1958) Notes on the growth and biology of the different Cardium species in the Danish brackish water areas. Medd Danm Fisk Havunders 2(22):1-31

Petersen GH, Russell PJC (1971) Cardium hauniense compared with C. exiguum and C. glaucum. Proc Malac Soc Lond 39:409-420

Rasmussen E (1973) Systematics and ecology of the Isefjord marine fauna. Ophelia 11:1-507

Reise K (1985) Tidal flat ecology. Springer, Berlin Heidelberg New York

Reise K (1996) Das Ökosystem Wattenmeer im Wandel. Geogr Rundschau 48:442-449

Reise K (2001) Algen und Seegras: grüne Matten und Wiesen im Watt. In: Landesamt für den Nationalpark SchleswigHolsteinisches Wattenmeer (ed) Wattenmeermonitoring 2000. Tönning, Germany, pp 55-56

Russell PJC, Petersen GH (1973) The use of ecological data in the elucidation of some shallow water European Cardium species. Malacologia 14:223-232

Rygg B (1970) Studies on Cerastoderma edule (L.) and Cerastoderma glaucum (Poiret). Sarsia 43:65-80

Schreitling KT (1963) Im Spülsaum der nordwestdeutschen Flachküste. Mitt AG Floristik Schleswig-Holstein Hamburg 11:1-105

Strasser M, Reinwald T, Reise K (2001a) Differential effects of the severe winter of 1995/96 on the intertidal bivalves Mytilus edulis, Cerastoderma edule and Mya arenaria in the northern Wadden Sea. Helgol Mar Res 55:190-197

Strasser M, Hertlein A, Reise K (2001b) Differential recruitment of bivalve species in the northern Wadden Sea after the severe winter of 1995/96 and of subsequent milder winters. Helgol Mar Res 55:182-189

Urk RM van (1973) Systematical notes on Cardium edule L. and Cardium glaucum Brug. in the Netherlands. Basteria 37:95-112

Wolff WJ (1992) The end of a tradition: 1000 years of embankment and reclamation of wetlands in the Netherlands. Ambio $21: 287-291$ 